\title{
sciendo OPTIMIZING THE USE OF HUMAN RESOURCES IN INDUSTRIAL-SERVICE ENTERPRISES
}

doi:10.2478/mape-2018-0108

Date of submission of the article to the Editor: 03/2018

Date of acceptance of the article by the Editor: $06 / 2018$
MAPE 2018, volume 1, issue 1, pp. 857-865

\author{
Mgr inż. Agnieszka Tychoniuk \\ Dr hab. inż. Ryszard Wyczółkowski, prof. PŚ \\ Silesian University of Technology, Poland
}

\author{
Vladimír Stuchlý \\ University of Žilina, Slovak Republic
}

\begin{abstract}
The optimal use of resources available in the enterprise is important regardless of the size of the company and the industry in which it operates. Enterprises are therefore forced constantly to make alternative choices related to the allocation of available resources and to optimize these choices. The article addresses the problem of the approach to optimizing the use of human resources particularly, the use of extra employee qualifications e.g., manual skills, pressure resistance, work precision, the ability to read schematic diagrams, etc. in the context of technical requirements for a given task. This is extremely important in the situation when subsequent works are individual and the conditions in which they will be performed, cannot be predicted in $100 \%$, they may differ from those that have been implemented so far, and at the same time numerous orders of various nature are being implemented. In this situation, an accurate prediction of the requirements posed by new tasks and the appropriate selection of teams executing them can have an impact on the effectiveness of the task completion process. In the article, this problem is presented on the example of a medium-sized service enterprise operating in the industry-related sector operating basically on tender procedures and tender contests. The works are carried out on the customer's premises, often with new customers or in new field conditions. Thus, the success of the undertaking depends mainly on the optimal selection of employees with appropriate qualifications and competences. The example of an investment task is used to show a method of identifying characteristics relevant to the task as well as selection of employees in order to use the capabilities of human teams better. Technical aspects of task implementation and an employees team selection with regard to the absolutely required technical qualifications as well as the behavioral and physical skills necessary for its implementation are taken into account. The described method can be used for future tasks regardless of the changing conditions of their implementation. The intention of the authors is to develop a tool supporting the decision-making process in this area, so that it can also be used by managers with lower technical competences.
\end{abstract}

Keywords: optimization, human resource allocation, competency, selection of employees, genetic algorithms

\section{INTRODUCTION}

The optimal use of resources available in the enterprise is important regardless of the size of the company and the industry in which it operates. Enterprises operating in an area with intensified competition wanting to maintain the quality of the products or services offered must seek new opportunities to reduce costs. It is connected with a number of decision problems related to the allocation of resources at their disposal, e.g. financial, human, technical or raw materials. The company's potential results from the structure, quality and ability to create optimal combinations of resources (Laslo and Golberg, 2008).

The condition and quality of all the organization's resources are very important, however, in the subject literature it is emphasized that human resources play crucial role today 
(Čižiūnienè et al., 2016; Ferjani et al., 2017; Jasiulewicz-Kaczmarek and Saniuk, 2015; Roszyk-Kowalska, 2016).

Making the right decisions is very difficult due to the dynamic nature of the company and its environment (Łatuszyńska and Lemk, 2013). Particularly, depending on the size of the organization, fluctuation of the executive and management staff, and in the lack of experience in evaluating employees and assigning them to tasks. Each employee has a unique set of attributes (soft skills) that have an additional impact on the effects of their work. It is emphasized that soft skills are equally important in the process of selecting employees for tasks, but there are no solutions indicating how to define these characteristics or assess their validity for a particular task (Hungs-Tso, 2010; Lichtarski, 2007). Resource planning in service enterprises regarding the need to take into account the different locations of use of the resources or involvement in many investment projects, can be compared to the use of resources in the production process in several workplaces. Such dynamic versions of assigning resources to tasks are solved by scheduling work (Hanczar, 2011). However, most of the computer systems used to support project management do not offer the possibility of scheduling optimization, allowing only its construction and quality assessment (Kostrubiec, 2007). This makes the analysis of economic effects is carried out after the construction of the schedule and not at the stage of the decision-making process. In the subject literature, it is difficult to find tips on how to create and implement quantitative models of resource allocation in the area of services (Hanczar, 2011). Perhaps the reason is too much diversity of requirements, which prevents the use of universal solutions. At present, the allocation of human resources to tasks is usually carried out based on subjective opinions or experience of people responsible for the composition of a task force. Therefore, to achieve optimal performance in a shorter time and at a lower cost, an effective model for optimizing the allocation of human resources should be ensured in order to improve the decision-making capability of the organization (Ni et al., 2017).

\section{ALLOCATION OF HUMAN RESOURCES}

In general, by allocating resources, we mean planning the use of resources that we have at our disposal in order to achieve specific goals in the future (Jasiulewicz-Kaczmarek et al., 2016). Employees belong to renewable resources, which after completing the tasks they are assigned to can be involved in another actions. The optimal manpower structure for a specific company is determined by its economic environment. In a dynamic environment, the company's work force has to be flexible. In a static environment, the individual jobholder can by specialized to handle only certain activities (Drexl and Mundschenk, 2008).

The most important goal of the allocation of human resources in service enterprises is to ensure their availability to carry out the tasks that make up a given service (Lan et al., 2013). What's more, the use of these resources must be tailored to the specific activities to which these resources can be assigned. In the selection of employees for the implementation of a specific task, their technical qualifications have a significant role to play, documented by certificates of completion of relevant courses/trainings, certificates, school-leaving certificates, etc. They are so-called 'hard competencies' that are necessary and can be verified by the participant of the service implementation process at every stage of its implementation.

From the point of view of the enterprise, planning the rational management of human resources in order to obtain the most effective outcome of the contract should be related to the use of the so-called 'soft competences' (Jasiulewicz-Kaczmarek et al., 2016; Lahiani et al., 2016). The following criteria play an essential role here:

- efficiency, such as: work efficiency, accuracy of performance, timeliness, effectiveness of operations, manual skills, 
- behavioural, for example, ability to make decisions, ability to work in a team, communication skills, resistance to stress, responsibility, ability to anticipate a risk, orderliness, attitude towards changes, creativity, ability to focus attention, the ability to logically reason,

- physical, such as the age of the worker, no fear of heights, the efficiency of the osteoarticular system.

It is also indicated (Fiasché et al., 2016), that each employee is characterized by a certain level of physical, sensory and cognitive abilities and a certain level of proficiency related to knowledge and skills. In addition, each employee has specific preferences regarding the positions to which they would like to be assigned. Similarly, it is assumed that each job requires a certain level of physical, sensory and cognitive abilities, as well as a certain level of relevant knowledge and skills.

Optimal allocation of employees to the implementation of tasks is a significant decision problem for the organizer of this process. It is connected with the necessity of analyzing a large number of data and the necessity of their multifaceted comparison.

In the problem of resource allocation besides its main element, which is the allocation of the resource to the activity or resource to the action in time, we also have to take into account the different locations of resource use (Hanczar, 2011). There are also different variants of the service implementation, which further complicate the allocation of resources. New tasks generally arrive before the end of the previous ones. They can run concurrently with already implemented processes and human resources can be temporarily allocated for the implementation of various tasks.

It happens that the object where the work is done is not temporarily available at the client's request (work in the mining plant's operation). There are also cases when ongoing works are interrupted in order to perform another more urgent task, assuming that their suspension will not affect the total time of execution of the contract. In this way, the problem of optimal allocation of these resources becomes even more complicated. Admittedly, this problem is usually dealt with by senior executives who have technical education, over the years of work in the field they have developed a routine that allows the assessment of organizational and technical aspects of the implementation of tasks. Above all, they know their employees well, they also have intuition and experience in planning the work and resources necessary for their implementation. There are, however, cases where an experienced manager is replaced by less experienced or with insufficient technical knowledge but with experience in the area of management, and who has at his disposal a team of employees consisting of several dozen people with different qualifications, experience and predispositions. In both cases, their operation would be more effective if they used tools supporting the human resources allocation process.

\section{SELECTION OF THE OPTIMAL COMPOSITION OF THE TASK TEAM}

The issue of an optimal resource allocation concerns a situation in which we have a certain amount of some homogeneous resource at our disposal (Gaspars-Wieloch, 2007). The goal of an optimal distribution of resources is to achieve the best effect with minimal investment. A properly selected team will use the advantages of a teamwork, whereas, ill-chosen team will cause resources waste (Twardochleb, 2014).

The concept of a system supporting the task of allocating human resources of an enterprise discussed in the further part of the article assumes the construction of a dynamic work schedule taking into account many variables: new incoming orders, orders in progress, availability of resources over time, etc.

The construction of such a system requires the resolution of the following issues: 
- a method of identifying characteristics relevant to the task description - e.g. through an expert assessment based on an in-depth analysis of the process carried out in the examined plant, including the generic division of tasks,

- a way of identifying characteristics relevant to the description of the task team participant - e.g. using a questionnaire to gather expert opinions (Shahhosseini and Sebt, 2011),

- matching the task relevant features to the characteristics of participants in the task team - e.g. using stochastic methods (Twardochleb, 2014),

- arranging the schedule of using human resources in the event of a stream of various tasks which appear in time with different intensity e.g. with the use of genetic algorithms (Ni et al., 2017).

Describing the task in the service process and determining its characteristic features is a rather complicated and time-consuming activity. This is due to the variability of many environmental and technical factors. The coordinator of the work preparing for the new task must answer at least the following questions:

- what technical aspects of the task completion can affect the problems with its implementation?

- who is the client and what were the previously completed tasks for this client, did any organizional poblems occur, and if so, what were they?

- how is a new task differenf from the previous task and what technical problems can occur during the implementation of it?

- what is the time of completing a new task in relation to a similar task and a team of employees performing it?

Without the tools supporting the decision-making process, it is based only on its own knowledge, knowledge of the industry in which it operates, experience gained on the basis of previously completed tasks, analysis of documentation from previously carried out similar tasks and information obtained from associate.

\section{THE CONCEPT OF A SYSTEM SUPPORTING THE ALLOCATION OF HUMAN RESOURCES}

The aforementioned problems related to the construction of a system supporting the allocation of human resources are also transferred to the concept of the system, as each stage of its construction is of various character and requires different tools and methods of operation. A block diagram including the most important stages of the proposed method is shown in Fig. 1.

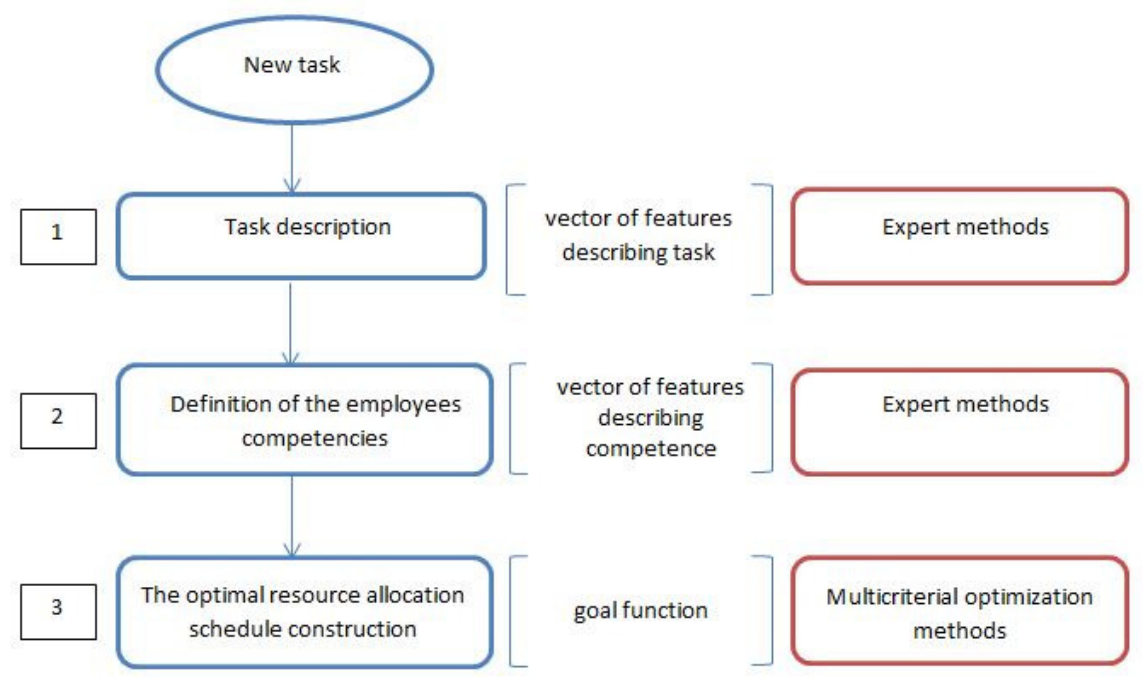

Fig. 1. Block diagram of the proposed method - based on own research 
Each new task contains some similar elements that can be compared to tasks already carried out. Having the knowledge of the implementation of previous tasks, it can be used to solve new problems arising from the implementation of a new task by adapting earlier solutions. It requires the use of the chosen method of searching and comparing tasks. A system based on the CBR (Case Based Reasoning) method is proposed, i.e. searching in the case database for the most similar examples to a user-defined system - Fig 2. The input to the support system is then the description (feature vector) of the task, and its response is the collection of desirable characteristics of the team performing this task.

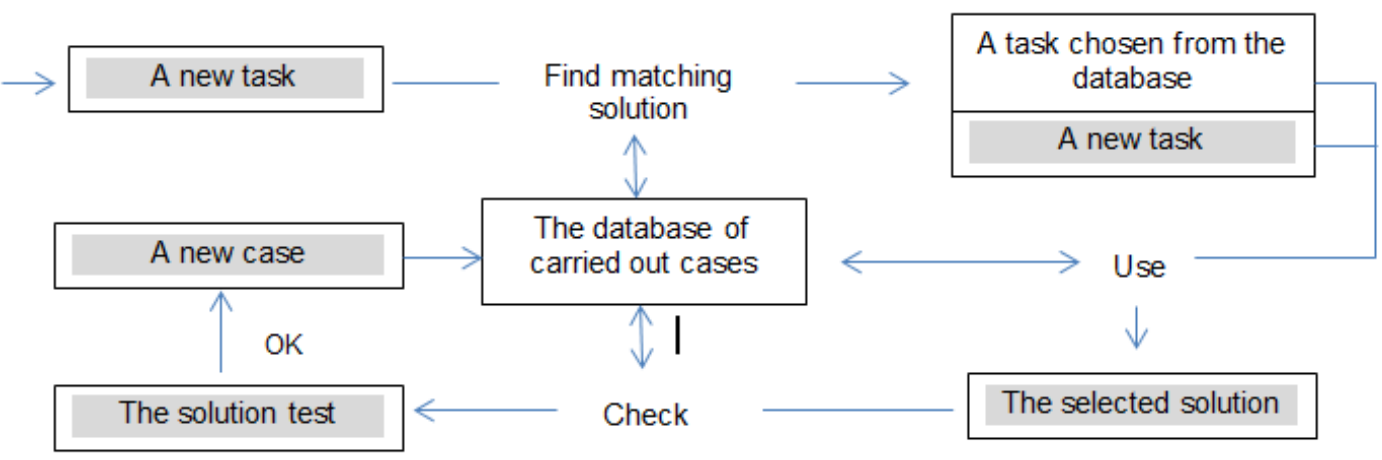

Fig. 2. The essence of the CBR method

Source: based on (Szelka and Wrona, 2014).

Practice shows that there is rarely a situation in which the case found is $100 \%$ similar to the reported problem (the environment, operating conditions, goals and business rules are different). When building a system of inference based on cases, the basic assumptions in the field should be adopted (Matusek, 2014):

1. What attributes should be used to describe the input (tasks to be carried out)?

2. How to distinguish sample, exemplary tasks?

3. How to determine the measure of similarity between tasks?

4. Which classification algorithm should be chosen?

To solve this task, the authors plan to use the following expert methods:

- an interview with experts to select model tasks,

- for the determination of relevant attributes, it is anticipated to apply of the assessment of experts supported by heuristic methods supporting assumptions for a project task, e.g. the goal tree,

- AHP method for determining the importance of features,

- conducting comparative tests of different classification methods for the choice of method used in the proposed CBR module,

- for this task, it will be necessary to prepare an appropriately labeled training set prepared with the participation of experts.

- testing different methods of classification of selected features.

Obtaining the optimal allocation of human resources taking into account the tasks already implemented and new requires the development of a multicriteria optimization method, which is to find the best solution to the problem. This means that the problem has more than one solution, and the solutions are not of the same quality.

The solution to the optimization task requires solving two partial problems:

1. building a formal problem model,

2. a choice the method of solving the task.

Building a formal problem model allows to use typical and already developed methods of solving it, or at least points out the methods that may be helpful in solving the problem but require some adaptation modifications. One of the typical models that can be used to 
describe formally the presented task is the so-called problem of fulfilling Boolean formulas (SAT). The task is then saved as a logical formula that can be represented as:

$$
F(x)=\left(x _ { 1 } \text { or } x _ { 2 } \text { or ....) and } \left(x_{4} \text { or } x_{5}\right.\right. \text { or ...) and .... }
$$

where each of the partial formulas $x_{i}$ describes one partial condition that is required to be satisfied for the task to be performed, e.g. an employee $x$ having the $y$-at $z$-feature is available.

This model will probably require modification, allowing to take into account the degree to which a given employee has a given feature, its importance for the task and the possibility of "substitution of employees" with tasks already performed. As the literature on the subject indicates, such task belongs to the so-called computationally difficult.

We do not have an analytical method to determine the optimal solution for it, and therefore we solve the problem by searching the field of possible solutions. The difficulty is that the number of possible variants that needs to be considered and assessed is growing rapidly with the increase in the size of the task.

Hence, for small tasks (a few orders, small number of employees) where the space of possible solutions is small, coming up with an optimal solution to a problem should not be a big issue - you can use different methods to search for a set of possible solutions. For larger tasks, where a large search scope is required, and moreover, the problem itself can change over time (Michalewicz and Fogel, 2014). In this case different heuristic methods, e.g. genetic optimization, are successfully used to solve the task. Then, we get a good solution, without a guarantee that it is the optimal solution.

\section{A SAMPLE TASK THAT ILLUSTRATES THE PROBLEM}

For the purposes of illustrating the problem being solved and the assumptions adopted, a medium-sized service enterprise was selected, which provides design, renovation, modernization, control and measurement services in the power and mining industries. The company has developed an organizational structure that determines the organizational subordination of individual employees and their place in the organization. The company under study acquires orders as part of inquiries, offer contests and, in particular, on the basis of tenders. The ability to compete in obtaining orders is primarily determined by meeting formal requirements of the Specification of Essential Terms of Contract (SIWZ) of the contracting entity. While the success in obtaining orders is related to the competitiveness of the offer price, which requires the company to optimize at the level of the work organization. The possibilities of reducing costs by purchasing at competitive prices the materials necessary for the implementation of investments can usually be considered depleted. Hence the reason to turn to optimization in the area of using available human resources while selecting teams to carry out tasks.

The assumptions of the system are illustrated on the example of the task of strengthening and sealing the shaft housing of one of the mining plants. The material scope of the task included, among others: repair of the damaged shaft glassembly by removing damaged fragments of the casing and filling the resulting defects with building material. An example of a list of features for the task of strengthening and sealing the shaft housing is presented in Table 1.

The description presented in Table 1 is a formal description of how the task may be presented in the documentation, e.g. tender. The proper interpretation of these records should be attached to the person who selects the working team. This task requires specific knowledge about the work being carried out. For example, there is a different approach to selecting employees for a task team in a shaft in which it is necessary to build work and safety platforms, where the worker with manual skills, no fear of heights, able to resist a long-lasting physical effort, stereoscopic vision and good physical and visual condition will be the most suitable. 
Table 1

Task features - Strengthening and sealing the shaft housing

\begin{tabular}{|l|l|l|}
\hline \multicolumn{1}{|c|}{ No } & \multicolumn{1}{|c|}{ Task feature } & \multicolumn{1}{c|}{ Feature description } \\
\hline 1. & Client & - mining plant ... \\
\hline 2. & Time of task completion & $-\ldots$ months \\
\hline 3. & Value of the contract & $-\ldots$ PLN \\
\hline 4. & Shaft type & - ventilation -air shaft \\
\hline 5. & Shaft shape & - round \\
\hline 6. & Shaft housing type & - masonry - concrete \\
\hline 7. & Shaft equipment & - girders \\
\hline 8. & Auxiliaries & - working platforms \\
\hline 9. & Means of communication & - Echo system \\
\hline 10. & The composition of the task team & $-\ldots$ persons \\
\hline
\end{tabular}

A worker who has all of the above features, except fear of heights, will not be able to work in this task, as working on the shaft is a threat both to him and other participants of the task team. In this case, it can perform preparatory functions (preparation and delivery of materials for a workstation) in the process of carrying out the work.

Another aspect is, for example, the matter of the aesthetics of making masonry work. In this case, it is not a key issue, but other masonry work (e.g. repair or building façade) may require high aesthetic performance. Each time the selection of employees for the task team is performed on the basis of the expert assessment of the work coordinator based on their own knowledge, experience, observation, analysis of previously performed tasks and the analysis of the contract and technical documentation of the task planned for implementation. Apart from technical qualifications required in the selection of an employee to the team, the following should be considered as well:

- knowledge resulting not only from experience but personal interests as well,

- resistance to stress,

- physical fitness,

- manual skills,

- ability to perform works quickly and accurately,

- openness of mind,

- involvement,

- responsibility,

- predictability in action,

- ability to anticipate the risk.

Furthermore, the employee who is the coordinator of the performed task, who is permanently in place and participates in the work should additionally:

- have leadership qualities,

- have knowledge in the technical area in which the work is carried out,

- be determined in action especially in crisis situations and requiring a quick and unambiguous decision.

The significance of these features may vary depending on the nature of the task, its characteristics and the individual assessment of the coordinator. It is also necessary to determine the manner of assessing the relevance of the individual characteristics of contractors from the point of view of the task realization. It can be assessed using weight scales or quality indicators. Each of the criteria (efficiency, behavioral, physical) consists of a selected and grouped set of features used to describe individual employees. The value of the assessment of these criteria shows to what extent the employee is suitable for the implementation of the selected task.

The attribution of the characteristics relevant to the task with the characteristics of task team participants and the allocation of human resources to tasks is therefore a significant problem 
in the process of employee allocation. This is related to the variety of factors to be considered. Among them, the following are important:

- time of task completion,

- the cost of its implementation,

- availability of human resources,

- availability of technical resources.

In summary, the appearance of a new task to be executed triggers the following decisionmaking process:

1. determines if a given task needs to be divided into subtasks,

2. defines what features the task or the subtasks separated from the team that performs them are required,

3. defines the hierarchy of importance of these features - the fulfillment of which feature is more important than the others,

4. employees selection for the team performing the task, however, an additional aspect of this task may be taken into account, including the possibility of transferring employees from other teams.

Obtaining detailed knowledge of the previously completed tasks and their effectiveness will require testing using the multiple case study method. Having ready testing patterns for the classification, it will be possible to use different methods, e.g. methods of closest neighbors (k-Nearest Neighbors).

\section{CONCLUSIONS}

Effective problem solving requires more than just knowledge of algorithms; it requires careful determination of the best combination of methods needed to achieve the preferred goal (Michalewicz and Fogel, 2004).

The article raises the problem of the allocation of human resources in the context of the use of additional efficiency, behavioral and physical qualifications of employees. They can have an equally important impact on the effectiveness of the task, such as technical qualifications resulting from the education or completed courses or trainings.

At present, the allocation of employees to tasks is usually carried out on the basis of subjective opinions or experience of people coordinating that work.

According to the authors of the article, it is possible to improve process efficiency in a shorter time and at a lower cost if the optimization model of human resources allocation is used to improve the decision-making power of the organization.

The article discusses the issue of applying the CBR method to solving the problem of employee allocation in a new task by searching for similar cases from the database of tasks already carried out.

Decision-making problems related to the allocation of human resources in service enterprises that carry out investment tasks in the field are heterogeneous and quite complex. They can find a solution using heuristic methods such as genetic algorithms or scenario methods (Loska, 2017).

The presented concept is the beginning of the work undertaken by the authors and requires a deeper analysis both in terms of tools and methods of optimization, as well as limitations that will determine possible solutions to the problem of allocation of human resources.

\section{ACKNOWLEDGEMENTS}

The paper is the result of statutory research carried out at the Institute of Production Engineering at the Faculty of Organization and Management of the Silesian University of Technology as part of a project number 13/030/BK_18/0039 called "Development of intelligent production methods as well as work and life environments in the context of production engineering challenges". 


\section{REFERENCES}

Čižiūnienè, K., Vaičiūtè, K., Batarlienè, N. (2016), Research on Competencies of Human Resources in Transport Sector: Lithuanian Case Study. Procedia Engineering, 134.

Drexl, A., Mundschenk, M. (2008). Long-term staffing based on qualification profiles. Manuskripte aus den Instituten für Betriebswirtschaftslehre der Universität Kiel.

Ferjani, A., Ammar, A., Pierreval, H., Elkosantini, S. (2017). A simulation-optimization based heuristic for the online assignment of multi-skilled workers subjected to fatigue in manufacturing systems. Computers \& Industrial Engineering, pp. 663-674.

Fiasché, M., Pinzone, M., Fantini, P., Alexandru, A. and Taisch, M. (2016). Human-Centric Factories 4.0: a Mathematical Model for Job Allocation. IEEE 2nd International Forum on Research and Technologies for Society and Industry Leveraging a better tomorrow (RTSI).

Gaspars - Wieloch, H. (2007). Alokacja zasobu w warunkach niepewności: modele decyzyjne i procedury obliczeniowe. Badania Operacyjne i Decyzje, 1.

Hanczar, P. (2011). Metody optymalizacyjne w planowaniu wykorzystania zasobów przedsiębiorstw usługowych. Prace Naukowe Uniwersytetu Ekonomicznego we Wrocławiu, 235.

Hungs-Tso, L. (2010). Personnel selection using analytic network proces and fuzzy data envelopment analysis approaches. Computers \& Industrial Engineering, 59.

Jasiulewicz-Kaczmarek, M., Saniuk, A. (2015). Human factor in Sustainable Manufacturing. In: M. Antona, C. Stephanidis, eds., Universal Access in Human-Computer Interaction. Access to the Human Environment and Culture, LNCS, 9178, pp. $444-455$.

Jasiulewicz-Kaczmarek, M., Saniuk, A., Nowicki, T. (2016). The maintenance management in the macro-ergonomics context. In: H. Richard, M. Goossens, eds., Advances in Social \& Occupational Ergonomics Series: Advances in Intelligent Systems and Computing, 487 pp. 3546.

Kostrubiec, A. (2007). Analiza skutków ekonomicznych zastosowania wybranych mrtaheurystyk w harmonogramowaniu projektów. Rozprawa doktorska.

Lahiani, N., El Mhamedi, A., Hani, J., Triki, A. (2016). A novel improving method of industrial performance based on human resources management. IFAC-PapersOnLine, 49(28), pp. 262267.

Lan, C-H., Chuang, L-L., Chen, Y-F. (2013). Optimal human resource allocation model: A case study of Taiwan fire service. Journal of Statistics and Management Systems, 14(1), pp. 187-216.

Laslo, Z., Golberg, A. (2008). Resource allocation under uncertainty in a multi - Project matrix environment: Is organisational conflict inevitable. International journal of project management, 26(8), pp. 773-788.

Łatuszyńska, M., Lemk, J. (2013). Zastosowanie modelowania modularnego w zarządzaniu zasobami produkcyjnymi. Studia i Prace WNEIZ US, 34(2), pp. 39-49.

Lichtarski, J. (2007). Specyfika doboru pracowników do struktur zadaniowych w teorii i praktyce. Zarzadzanie zasobami ludzkimi.

Loska, A. (2017). Scenario modeling exploitation decision-making process in technical network systems. Eksploatacja i Niezawodność - Maintenance and Reliability, 19(2), pp. 268-278.

Matusek, M. (2014). Koncepcja systemu wyboru dostawcy z wykorzystaniem metody wnioskowania na bazie przypadków. Zeszyty Naukowe Politechniki Śląskiej.

Michalewicz, Z., Fogel, D. B. (2004). How to Solve It: Modern Heuristics. Springer Science \& Business Media.

Ni, L., Yuhong, L., Mengyuan, S., Haipeng, K., Guanghong, G. (2017). An optimization method for task assignment for industrial manufacturing organizations.

Roszyk - Kowalska, G. (2016). Chosen methods tools for measuring managerial competencies, Journal of human resource management.

Shahhosseini, V., Sebt, M. H. (2011). Competency - based selection and assignment of human resources to construction projects. Scientia Iranica, 18(2).

Szelka, J., Wrona, Z. (2014). Wnioskowanie w systemach z wiedzą niepełną w przedsięwzięciach inżynieryjnych. Budownictwo i Architektura.

Twardochleb, M. (2014). Project team selection using stochastic methods. Business Informatics. 